\title{
Sprawozdanie z międzynarodowej konferencji pt. Konference mladých slavistů XII. Neslovanské elementy $v$ kulturách a jazycích Slovanů, Praga, 3-4 XI 2016 r.*
}

W dniach 3-4 XI 2016 r. odbyła się 12 edycja międzynarodowej konferencji organizowanej przez Instytut Wschodnioeuropejski Uniwersytetu Karola w Pradze. Konferencja była przeznaczona dla doktorantów z całej Europy. W tym roku organizatorzy postanowili zachęcić uczestników do rozważań nad niesłowiańskimi elementami, które można odnaleźć w kulturze czy językach Słowian, a na miejsce obrad wybrano Wydział Filozoficzny w Pradze.

Konferencja Młodych Slawistów to projekt studentów i doktorantów zajmujących się badaniami poświęconymi krajom Europy Środkowo-Wschodniej. Jej głównym celem, w założeniu organizatorów, jest nawiązywanie kontaktów naukowych, które skutkować mogą przyszłą, międzynarodową współpracą młodego pokolenia badaczy.

Pierwszego dnia konferencji, po rejestracji uczestników i oficjalnym przywitaniu wszystkich gości przez władze Instytutu, rozpoczęto obrady. Podzielono je na dwie sekcje: historyczną oraz literacką. W pierwszej mogliśmy wysłuchać czterech referatów poświęconych historii Słowian od średniowiecza aż po czasy współczesne. Z kolei w sekcji literackiej liczba referentów wzrosła do 11 uczestników, a dyskutowano na tematy związane z literaturą czeską, chorwacką czy węgierską.

Drugi dzień rozpoczęto kontynuacją sekcji literackiej, lecz tym razem dane było nam wysłuchać jedynie czterech referatów. Po ożywionej dyskusji rozpoczęła się

\footnotetext{
* Praca finansowana w ramach projektu Narodowego Centrum Nauki SYMFONIA 2, nr UMO-2014/12/W/NZ2/00466.
} 
sekcja językowa z ośmioma uczestnikami. Ostatnią, zamykającą konferencję sekcję, poświęcono kulturze, a swoje badania przedstawiło czterech uczestników, co ciekawe wszyscy pochodzili z polskich ośrodków naukowych.

Należy zaznaczyć, iż organizatorzy wskazali, iż każdy język słowiański jest językiem konferencyjnym. Zaowocowało to tym, że uczestnicy przyjechali z różnych państw europejskich. Najwięcej referentów dotarło z Polski, jednakże nie zabrakło także doktorantów z Białorusi, Czech, Chorwacji, Słowacji, Słowenii, Rosji, Ukrainy, Węgier, a nawet Estonii czy Turcji. Polskę reprezentowali studenci z Uniwersytetu Jagiellońskiego, Uniwersytetu Gdańskiego, Uniwersytetu Marii Curie-Skłodowskiej w Lublinie, Uniwersytetu Śląskiego w Katowicach oraz Uniwersytetu im. Adama Mickiewicza w Poznaniu. Przedstawicielami ostatniej z wymienionych wyżej uczelni, było dwóch doktorantów Wydziału Historycznego. Pierwszego dnia, mgr Jakub Wojtczak przeanalizował polityczne aspekty, towarzyszące małżeństwom Świętosławy Sygrydy (córki Mieszka I) z Erykiem Zwycięskim i Swenem Widłobrodym (Polsko-skandynawskie mariaże dynastyczne - uwarunkowania polityczne i skutki). Drugiego dnia mgr Robert T. Tomczak zaprezentował zagadnienie orientalnych elementów w szesnastowiecznej i siedemnastowiecznej kulturze Rzeczypospolitej Obojga Narodów (Wplywy orientalne w kulturze Rzeczypospolitej Obojga Narodów w XVI-XVII wieku). Dodatkowo obaj doktoranci wspólnie przygotowali poster, poświęcony skandynawskim skarbom archeologicznym, które odkrywano na ziemiach polskich.

Konferencja cieszyła się dużym zainteresowaniem. Świadczyć o tym może fakt, iż niemal każde wystąpienie doczekało się ożywionej dyskusji, co przyczyniło się do przekroczenia ram czasowych i trwania konferencji o wiele dłużej, niż przewidzieli organizatorzy. Należy zaznaczyć, że tego typu wydarzenia, zrzeszające młodych naukowców pochodzących z różnych państw europejskich, zaowocować mogą nie tylko wymianą doświadczeń, ale również późniejszą współpracą. Miejmy nadzieję, że organizatorzy znów postanowią zorganizować kolejne, międzynarodowe spotkanie na Uniwersytecie Karola.

\author{
mgr JaKub WoJTCZAK \\ Instytut Historii \\ Wydział Historyczny \\ Uniwersytet im. Adama Mickiewicza \\ ul. Umultowska 89d \\ 61-614 Poznań \\ kub.wojtczak@gmail.com
}

